\title{
Do citizenship regimes shape political incorporation? Evidence from four
}

\section{European cities}

Pre-journal version of the article published in EPS, 2013,

http://dx.doi.org/10.1057/eps.2013.15

\section{Authors:}

Amparo González-Ferrer, Research Fellow, Institute of Economy, Geography and Demography (IEGD), Center for Humanities \& Social Sciences (CCHS), Spanish National Research Council (CSIC) Albasanz, 26-28. 28037 Madrid. Tel: +34 916022600. Email: amparo.gonzalez@cchs.csic.es

Laura Morales, Reader in Politics, Department of Politics and International Relations, University of Leicester. University Road, Leicester LE1 7RH, UK.

Tel: +44 (0)116 252 2727. Fax: +44 (0)116252 5082. Email: 1m254@1e.ac.uk 


\title{
Do citizenship regimes shape political incorporation? Evidence from four European cities
}

\author{
Abstract \\ We examine how different formal citizenship regimes fare in achieving the political \\ inclusion of immigrants and their children by looking at voting turnout in local \\ elections. We analyse survey data from four European cities that grant voting rights to \\ foreigners but are located in countries with contrasting rules for access to formal \\ citizenship. Local voting gaps are larger where citizenship rules are more restrictive, \\ which suggests that citizenship regimes have long-lasting effects on political \\ inclusion.
}

KEYWORDS: immigration, citizenship, electoral participation, local elections, voting turnout.

Running title: Do citizenship regimes shape political incorporation? 


\section{Do citizenship regimes shape political incorporation? Evidence from four European cities}

\section{Introduction}

The exclusion of immigrants and their descendants from political voice challenges normative beliefs about democratic equality, undermines the process of democratic representation and accountability, and could contribute to their social and economic exclusion (Jones-Correa, 1998). Voting is one key part of political inclusion, ${ }^{1}$ as it provides immigrants and their children with an opportunity to participate in the selection of their democratic representatives, and to shape policy making in the places where they live.

Indeed, recognizing the importance of suffrage for immigrants' integration, various countries and cities across Europe — including those studied in this article have granted local voting rights to non-(EU) citizens. This extension of voting rights has happened not only in societies with more inclusive citizenship legislation, such as Sweden or the United Kingdom, but also in places where access to national citizenship is more restricted, as in Norway and Switzerland. Thus, there is no perfect correspondence between the inclusiveness of formal citizenship rules and the rules governing local voting rights for non-citizens.

In this article we examine whether the openness or restrictiveness of citizenship acquisition rules — generally determined by national legislation — has a lasting effect on the political inclusion of immigrant-background minorities, even in settings where formal barriers to their political participation have been significantly lowered. Do national citizenship regimes shape the electoral behaviour of migrant 
minorities, and sustain political inequalities in access to the political process, even when local voting rights are granted to foreigners?

We contend that national citizenship rules still matter. The rules of access to formal citizenship are an influential expression of the receiving country's vision and philosophy in relation to the inclusion of immigrants. Formal citizenship rules are likely to influence the perceptions of immigrants and their children about how much the receiving societies welcome them as members of the polity and, consequently, will reinforce (or reduce) the inclusionary effect of local voting rights for foreigners. In order to assess the hypothesis that formal citizenship rules shape political inequalities at the local level, even in the absence of formal barriers to participation in local elections, we examine voting turnout gaps between migrants and autochthonous populations in four European cities: Geneva (Switzerland), Oslo (Norway), London (United Kingdom) and Stockholm (Sweden). ${ }^{2}$ 
These four cases are similar in that they all are large cosmopolitan cities where foreign residents have been granted local voting rights. Yet they are located in countries with substantially different formal citizenship regimes according to various existing typologies (Koopmans et al., 2005, Niessen et al., 2007) and policy indices like the Citizenship Policy Index (Howard, 2009) and the Migrant Integration Policy Index (MIPEX, Huddleston et al., 2011). All of them agree that Sweden and the UK have some of the most liberal citizenship legislations in Europe, whereas Norway's and Switzerland's are among the most restrictive ones.

In the next section we discuss how citizenship models may shape voting turnout for immigrants and their children. Then we present the data and describe the methods employed. We follow with a discussion of the results, and conclude by highlighting the theoretical and policy-relevant underpinnings of our findings. To anticipate our main results, we find that regardless of inclusive local voting rules, voting turnout gaps between migrant-background and autochthonous electors seem to reflect differences in citizenship rules: voting gaps are larger where citizenship rules are more restrictive.

\section{How citizenship models shape the electoral participation of immigrant-background} voters

Different citizenship models, designed mostly at the national level, have been shown to display a substantial impact on the degree of (and paths to) political integration of immigrants and their children (Ireland, 2000, Koopmans and Statham, 2000, Bloemraad, 2006). In particular, they have been shown to be important in shaping different patterns of collective mobilization and political claims-making by immigrants and ethnic minorities (Koopmans et al., 2005, Giugni and Passy, 2004, Cinalli and Giugni, 2011). However, the evidence is limited and less conclusive when the outcome 
to be explained is voting turnout (González-Ferrer, 2011) and the scarce comparative studies available do not address this issue directly (Bird et al., 2011).

Despite these early findings concerning the relevance of national citizenship models for immigrants' political participation, some authors have argued that variations within countries, especially at the local level, are also consequential in shaping the integration of immigrant-background minorities (Bousetta, 2000, Garbaye, 2002, Morales and Giugni, 2011). These studies emphasize that local councils enact policies that shape migrants' everyday lives, including their opportunities and incentives for political participation, not necessarily in a consistent way with the national policies. Granting local voting rights for foreigners is viewed as a good example in this regard, since it may somehow counterbalance the political inequalities that remain at the national level for immigrant populations, and promote their integration. However, the relative importance of the local versus the national opportunity structures has hardly been empirically examined.

We contend that there are reasons to expect that local opportunities for participation will only have a limited capacity to shape the political integration of migrant minorities, even if local voting rights are granted to foreigners, and that national citizenship models will still exert a powerful influence. Citizenship regimes send signals about who 'belongs to us' and is welcome as a full member of the social and political community, and who is not. Countries that establish very demanding conditions for naturalization often justify their approach as the way to ensure that their new citizens are as similar as possible to the native-born in aspects like language fluency, allegiance to the country, and civic values. However, it is not self-evident that by imposing longer waiting periods and tougher requirements to apply for citizenship, these countries will select individuals who are also more similar to natives in terms of their political 
orientations, their interest in politics and their attachment to the host country. In other words, more restrictive formal citizenship regimes send an exclusionary message to people of immigrant background, and this message might not be automatically off-set by extending local voting rights to foreigners.

Immigrants and their descendants are a very heterogeneous group with respect to their citizenship status and place of birth. First generation immigrants are born (and in most cases raised and socialized) in the country of origin, whereas second generations are all native to the country of their parents' settlement. Yet, in many European countries, both first and second generations include citizens (through naturalization, by birth, or by acquisition at a young age) and foreigners. Thus, for first generation migrants, citizenship rules determine how long they need to wait before they can naturalize. For second generations more restrictive citizenship rules mean that they are socialized into politics as foreigners in the country where they were born and raised, which may lead to detachment and feelings of alienation. This circumstance could reduce the assimilative effect of being born and raised in the country. In fact, some scholars refer to the differing levels of integration among first and subsequent generations as the "immigrant paradox," suggesting that the first generation shows higher levels of adaptation to the post-migration context than the second, and that overtime adaptation of the native-born youth may decline (Berry et al., 2006). As a consequence, for both first and second generation residents, we hypothesize that in places where citizenship rules are more restrictive, all immigrant-background residents will be less inclined to vote in elections than the autochthonous population, even if local opportunities to participate are ample because of extended voting rights for foreigners.

\section{Cases, hypotheses, data and methods}


To examine if voting gaps in local elections vary in a consistent way with formal citizenship regimes, we compare four cities that have all granted local voting rights to foreigners but that are located in countries with different rules concerning citizenship acquisition: Geneva, Oslo, Stockholm and London. Foreigners are required twelve, seven and five years of residence in Geneva, Oslo and Stockholm, respectively, to apply for naturalization; in London, only three. In addition, native-born children of foreign immigrants are not automatically citizens in the former three cities, because ius sanguinis prevails. However, whereas in Geneva and Oslo they can enter adulthood as foreigners, in Sweden, the liberal regime of citizenship acquisition by notification after five years of residence means that most children of permanent foreign residents will be citizens well before adolescence. In the UK, ius soli dominates and all native-born children of foreign residents with indefinite leave to remain are automatically British nationals.

Both Howard's (2009) Citizenship Policy Index (CPI) for 1980 and 2008, and the Migrant Integration Policy Index (MIPEX) for 2007 and 2010 confirm that Switzerland and Norway are appropriately described as closed or restrictive citizenship regimes, whereas Sweden and the UK can be described as more liberal in their citizenship rules. In all tables and figures we order the cities from more restrictive (Geneva) to more liberal (Stockholm), in accordance with the relative ranking provided by MIPEX (Table 1).

\section{[TABLE 1 AROUND HERE]}


Despite these different national citizenship rules, the four cities are comparable in several important aspects: they are centres of large metropolitan regions with strong economies, and in all of them migrant-background individuals constitute a sizeable minority with potentially large electoral leverage. As summarized in Table 2, all four cities have a substantial migrant-background population, with the share of migrantorigin residents ranging from 20 per cent of the population (in Stockholm) to as much as half of all residents, in the case of London. They all recognize local voting rights to foreigners, although in Geneva, eight years of residence are required to be eligible, whereas in Oslo and Stockholm this requirement drops to three, and in London, there is no minimum length of residence.

\section{[TABLE 2 AROUND HERE]}

Our theoretical expectation is that voting turnout gaps between immigrantbackground individuals and the majority population will be larger in the cities with more restrictive national citizenship rules (Hypothesis 1) - Geneva and Oslo - and especially for the non-citizen voters (Hypothesis 2). Moreover, as explained before, we expect these larger gaps in Geneva and Oslo not only for first but also second generations.

The data employed to assess these hypotheses comes from the Localmultidem Project, a collaborative European project that conducted surveys with representative random samples of immigrant-background and autochthonous populations in several European cities between 2003 and 2008. In each of the cities, the survey targeted a control group of autochthonous residents and two or three groups of immigrant origin. The immigrant- 
background groups were selected so that they were sizeable groups in each city, and that they represented different waves of migration and religious backgrounds (see Table 2). ${ }^{\text {iii }}$ Immigrant-origin respondents were targeted irrespective of citizenship or legal status, as long as they had resided in the city for at least six months. Our analysis focuses on respondents eligible to vote in local elections, which results in subsamples of various sizes across the cities that reflect differences in the local residency requirements. ${ }^{\text {iv }}$

The questionnaires included a wide range of items from basic sociodemographic individual characteristics to detailed information about respondents' political and civic engagement. Respondents were asked about their country of birth, year of arrival in the country and city of residence, educational level, language fluency, marital and employment status. Crucial for our analysis, they were also asked to list the citizenship(s) they held at the time of the survey, as well as their citizenship(s) at birth and that of their parents (sometimes even their grandparents'). The questionnaire asked about eligibility and electoral participation in the most recent national, regional and local elections of the country of residence. ${ }^{\mathrm{v}}$ Thus, we can examine voting turnout gaps between different subgroups of the population with an immigrant background and the autochthonous population (our reference group).

\section{The voting turnout gap for immigrants and their children}

We find substantial cross-city variation in voting turnout rates for local elections, as seen in Table 3. In most cases, both first and second generations are less likely to vote than the autochthonous, with the exception of the naturalized first generations in London and Stockholm, both located in countries with more liberal citizenship regimes. 
In contradiction with the assimilation approach — that would expect the voting turnout rates of second and subsequent generations to assimilate to the autochthonous ones -, second generation citizens are less inclined to vote than the naturalized first generation in their respective cities, with the only exception of Geneva, where both groups show similar voting rates. This result could be because of the younger age profile, on average, of the second generation citizens, but formal citizenship might also have a role to play. Second generation residents with granted citizenship vote more than first generation foreigners (except in Stockholm), but growing up in the country produces no differences in voting turnout when the second generation remain foreigners into adulthood. Thus, foreign voters, regardless of whether they are first or second generation, have, as expected, a lower voting turnout, which supports our main contention that suppressing formal barriers to voting rights at the local level does not automatically erase political exclusion.

Finally, it is interesting to note that for the only two cases where we had sufficient samples of children of mixed marriages (Geneva and London), they show opposite patterns. In Geneva, their voting rates are more similar to the native population than to second generations while in London it is indistinguishable from the other immigrant-background groups. This result supports previous scholarship that suggests that children of mixed marriages should not be automatically lumped together with those who have no native-born parent, as their political behaviour differs substantially from the latter (Ramakrishnan, 2004).

[TABLE 3 AROUND HERE] 
Overall, these results are broadly consistent with our expectation that turnout gaps between immigrant-background individuals and the autochthonous population will be larger in those societies with more restrictive citizenship acquisition rules (Hypothesis 1), as voting turnout gaps are larger in Oslo and Geneva than in London and Stockholm. The results are also consistent with the hypothesis that these gaps will be larger for the foreign voters (Hypothesis 2), as they are vastly larger in Geneva than in all other cities. ${ }^{\mathrm{vi}}$ Additionally, as we anticipated, these results also challenge the idea that the greater 'selectivity' intended by more restrictive naturalization regimes will translate automatically into greater political integration or assimilation. We do not find that naturalized immigrants who live in countries where access to citizenship is made more difficult have turnout rates that 'assimilate' them more to the autochthonous population.

Nevertheless, some of the differences between the majority population and immigrant-background individuals might be accounted for by different sociodemographic characteristics across groups and generations. Therefore, we conducted multivariate logistic regressions of voting turnout in local elections to estimate the voting gaps once key characteristics associated with voting are controlled for. We summarise the main results in Figure 1, which depicts the probability of voting (the solid diamond) for each of the relevant groups we want to compare, and the 95 per cent confidence intervals of the estimation of the probabilities (the bars). ${ }^{\text {vii }}$ The first overall result is that, in most cases, the voting turnout gaps between autochthonous and immigrant-background electors are small in magnitude, except in Geneva, which is in line with our initial expectation of larger gaps in most restrictive citizenship regimes.

However, the main finding is that, rather than generational differences, what matters most in local voting turnout rates is the national citizenship status: in all cities 
foreigners are between a half and a third less likely to cast a ballot than the autochthonous population. This is fully consistent with Hypothesis 2. Moreover, the voting turnout gap between foreign voters and the autochthonous population is largest in the society with the most restrictive citizenship regime (Geneva) and smallest in the society with the most liberal one (Stockholm), as Hypothesis 1 predicted.

[FIGURE 1 AROUND HERE]

The results of the model also suggest that age is positively related to turnout in all cities, whereas gender is only a significant predictor in London, with a negative effect. Educational attainment is in all cases but Oslo positively related to the inclination to vote while being employed only matters in London and Oslo. ${ }^{\text {viii }}$ In terms of other integration indicators, it is interesting to note that having an autochthonous spouse/partner is only important in Geneva, the proportion of one's life spent in the country is only relevant in Geneva and Oslo, and language fluency is not a significant predictor in any of the cities studied primarily because most of the eligible voters are fluent in the language of the country/locality. ${ }^{\text {ix }}$

\section{Conclusions}

Our analyses indicate that there is some evidence to support widely held views about the effect of national citizenship models on migrants' political engagement, at least when judged by their voting turnout in local elections. A turnout gap between immigrant-background and autochthonous residents exists in all cities. This gap is to some extent attributable to socio-demographic characteristics, such as age and educational levels. However, after controlling for socio-demographics, the gap remains 
significant and larger in cities with more restrictive national citizenship models Geneva and Oslo. One reason that some countries enact more restrictive citizenship regimes is that they see this policy as a pathway to greater political integration. Yet, our results challenge this assumption, as voting turnout gaps between the naturalized immigrants and the autochthonous population are larger in countries with more restrictive citizenship regimes.

On the other hand, the dominant view that voting turnout gaps should be larger for first generation immigrants than for their native-born children, in line with the assimilation hypothesis, is also not supported by our results. We find only marginal differences between generations once citizenship status is taken into account. Moreover, the voting turnout gap between the autochthonous population and the native-born second generation of immigrant-background is non-existent in the two societies with more open citizenship rules, but significant for the two cases with more restrictive approaches to nationality acquisition. The voting turnout gap is particularly large in the Swiss case, where citizenship rules are most restrictive and where many native-born children of immigrants grow up as foreigners in the only country they have ever lived in.

In conclusion, while the evidence with four cases can only be suggestive, our data indicate that different approaches to formal citizenship shape the patterns of local voting behaviour of immigrant-background individuals. Contrary to the prevalent view, there is some evidence to suggest that the effects are as large for the native-born children of immigrants as for first generations. If this is the case, restrictive citizenship approaches at the national level may have the perverse result of sustaining the political inequalities affecting most first generation migrants at the local level, even if formal barriers to electoral participation are suppressed. Moreover, these inequalities may even 
perpetuate over generations, possibly through political socialization mechanisms.

However, more research is needed to ascertain whether these effects and their direction are consistent in a larger number of societies, and whether patterns are the same for national elections. 


\section{TABLES AND FIGURES}

Table 1. Formal rules on access to formal citizenship in our selected countries

\begin{tabular}{|c|c|c|c|c|c|c|c|c|c|c|}
\hline & \multicolumn{2}{|c|}{ Ius Solis } & \multicolumn{2}{|c|}{$\begin{array}{l}\text { Length of } \\
\text { residence } \\
\text { requirement }\end{array}$} & \multicolumn{2}{|c|}{$\begin{array}{c}\text { Dual } \\
\text { Citizenship }\end{array}$} & \multicolumn{2}{|c|}{$\begin{array}{c}\text { Citizenship } \\
\text { Policy } \\
\operatorname{Index}^{1}(0-6)\end{array}$} & \multicolumn{2}{|c|}{$\begin{array}{c}\text { Ranking } \\
\text { MIPEX }^{3} \\
(0-100)\end{array}$} \\
\hline & 1980 & 2005 & 1980 & 2005 & 1980 & 2005 & 1980 & 2005 & 2007 & 2010 \\
\hline Switzerland & No & No & 12 & 12 & No & Yes & 0 & 2 & 36 & 36 \\
\hline Norway $^{2}$ & No & No & 7 & 7 & No & No & 1 & 1 & 41 & 41 \\
\hline Sweden $^{2}$ & No & No & 5 & 5 & No & Yes & 2 & 4 & 79 & 79 \\
\hline UK & Yes & Yes & 3 & 3 & Yes & Yes & 6 & 6 & 75 & 59 \\
\hline
\end{tabular}

Notes:

1 The Citizenship Policy Index distinguishes between countries that can be considered "liberal", "medium" or "restrictive" in their granting of citizenship, according to the score given to each of the three key components of their citizenship laws and practices: citizenship by birth, residency requirements for naturalization and acceptance of dual citizenship for immigrants. The resulting index varies from 0 (most restrictive) to 6 (most liberal).

${ }^{2}$ Howard's original CPI did not include either Switzerland or Norway, since they are not EU countries. We have collected the necessary information and followed the coding rules given in the Appendix of Howard (2005) to classify these two countries accordingly.

${ }^{3}$ MIPEX collects a larger number of indicators than CPI, and weights differently dual citizenship. The resulting scores range from 0 (most restrictive) to 100 (most liberal). 
Table 2. The cities

GENEVA

OSLO

25

2005

8

Length residence required to vote

Additional requirements

Registration for some

No

EU or Commonwealth

citizen + registration

Localmultidem Survey

Year of survey

Migrant groups included in survey

$$
\text { 2006-07 }
$$

Italians \& Kosovars
LONDON $^{1}$

0.8

$50.6^{2}$

1949

1975

0

STOCKHOLM

3

No

2003-04

Bangladeshi, Black-

Chilean \& Turkish
2004

Bosnian, Pakistani \&

Turkish

Source: Population, OECD Regional Statistics, 2006-2007 (TL3 level); percentage migrants, respective local government statistics.

${ }^{1}$ Only for the North Inner London boroughs of Islington, Camden, Hackney, and Haringey.

${ }^{2}$ Ethnic minority population, not foreign-born population. The foreign born were 33 per cent in 2010. 
Table 3. Self-reported turnout rates in local elections by group and city, percentages ( $\mathrm{N}$ of eligible voters)

\begin{tabular}{|c|c|c|c|c|}
\hline & GENEVA & OSLO & LONDON & STOCKHOLM \\
\hline \multirow[t]{2}{*}{ Autochthonous } & 73 & 87 & 44 & 87 \\
\hline & (159) & (297) & (227) & (319) \\
\hline \multirow[t]{2}{*}{ 1st generation citizens } & 54 & 62 & 46 & 87 \\
\hline & (110) & $(477)$ & (171) & (287) \\
\hline \multirow[t]{2}{*}{$1^{\text {st }}$ generation foreigners } & 37 & 41 & 23 & 72 \\
\hline & (170) & $(220)$ & (150) & (83) \\
\hline \multirow[t]{2}{*}{$2^{\text {nd }}$ generation citizens } & 55 & 52 & 30 & 64 \\
\hline & (56) & (75) & (407) & (79) \\
\hline \multirow[t]{2}{*}{$2^{\text {nd }}$ generation foreigners } & 5 & 50 & -- & -- \\
\hline & (21) & (8) & (1) & (4) \\
\hline \multirow[t]{2}{*}{ Children mixed couples } & 72 & 73 & 30 & 71 \\
\hline & (89) & (11) & (70) & (14) \\
\hline Total eligible voters & $(605)$ & $(1088)$ & $(1026)$ & (776) \\
\hline Ratio migrants/autocht. & $0.67 * *$ & $0.64 * *$ & $0.72 * *$ & $0.93^{*}$ \\
\hline Ratio $1^{\text {st }}$ citizens/autocht. & $0.74 * *$ & $0.71 * *$ & 1.04 & 1.00 \\
\hline Ratio $1^{\text {st }}$ & $0.51^{* *}$ & $0.47 * *$ & $0.52 * *$ & $0.83 * *$ \\
\hline \multicolumn{5}{|l|}{ foreigners/authocht. } \\
\hline Ratio $2^{\text {nd }}$ citizens/authocht. & $0.75^{* *}$ & $0.70 * *$ & $0.68 * *$ & $0.73 * *$ \\
\hline Ratio $2^{\text {nd }}$ foreigners/autocht. & $0.07 * *$ & $0.57 * *$ & -- & -- \\
\hline Ratio mixed/autochthonous & 0.99 & 0.84 & $0.68^{*}$ & 0.82 \\
\hline
\end{tabular}

Notes: * and $* *$ indicates that the cross-group differences are significant at 0.05 or 0.01 level, respectively. -- Not enough cases. 
Figure 1. Predicted probabilities of voting in local elections, by city and group

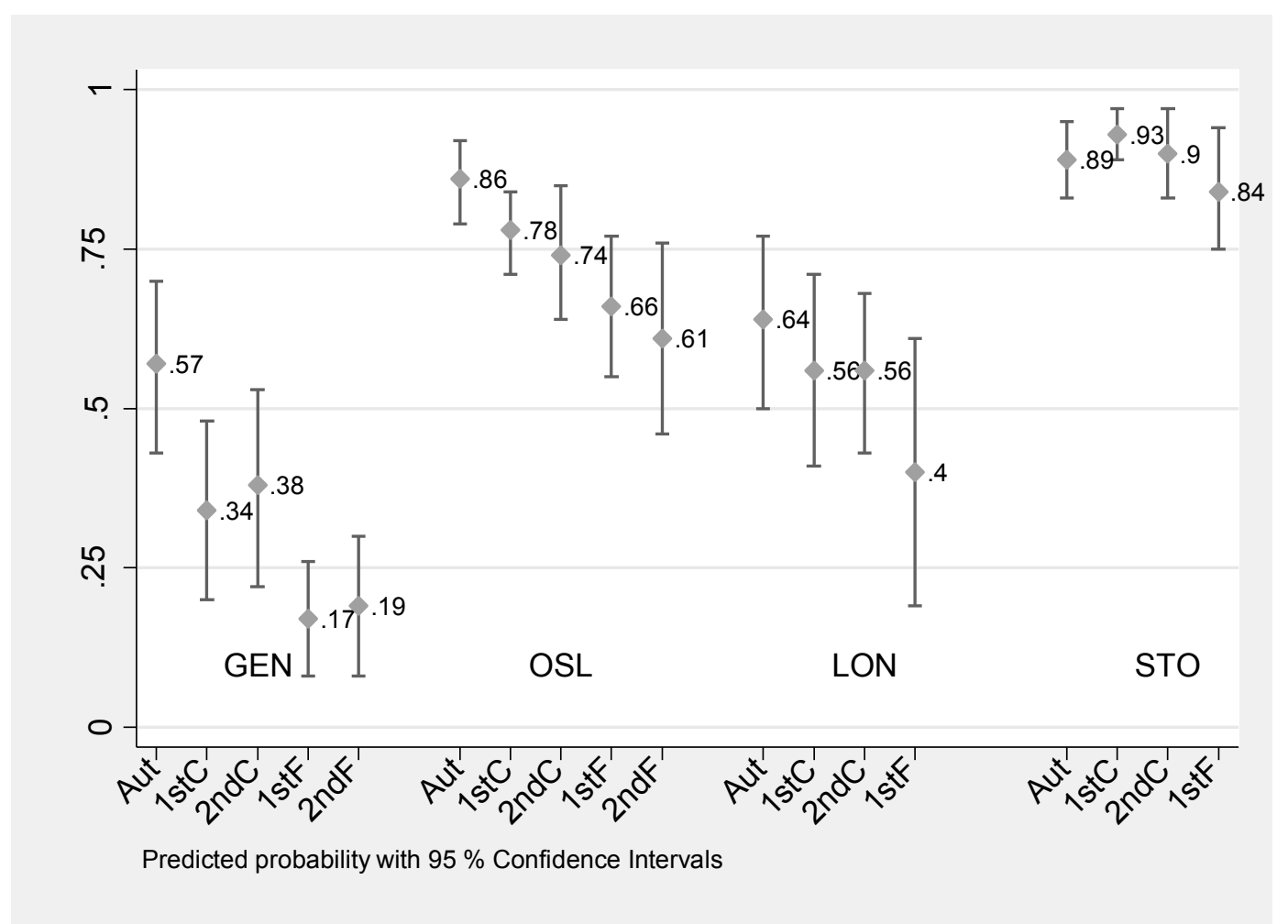

Legend: Aut $=$ autochthonous; $1 \mathrm{stC}=1^{\text {st }}$ generation citizen; $2 \mathrm{ndC}=2^{\text {nd }}$ generation citizen; $1 \mathrm{stF}=1^{\text {st }}$ generation foreigner; $2 \mathrm{ndF}=2^{\text {nd }}$ generation foreigner. $\mathrm{GEN}=\mathrm{Geneva}, \mathrm{OSL}=\mathrm{Oslo}, \mathrm{LON}=$ London, $\mathrm{STO}=$ Stockholm. 


\section{NOTES}

${ }^{1}$ Other forms of political inclusion — both attitudes and behaviours — are analysed in Morales and Giugni (2011).

${ }^{2}$ Results presented in this article stem from integrated datasets produced by the project 'Multicultural Democracy and Immigrants' Social Capital in Europe: Participation, Organisational Networks, and Public Policies at the Local Level (LOCALMULTIDEM)'. This project was funded by the European Commission under the $6^{\text {th }}$ Framework Programme's Priority 7 'Citizens and Governance in a Knowledge-Based Society' as a STREP instrument (contract no. CIT5-CT-2005-028802). Additionally, the Swedish and Norwegian data were collected with funding from the Sweden Tercentenary Foundation, the Swedish Council for Working Life and Social Research, and the Research Council of Norway, respectively. The data for Geneva was collected with funding from the Swiss National Science Foundation (grant no. 100012-109429). The authors want to acknowledge the work of the following colleagues in the production of the original datasets: Marco Giugni, Mario Diani, Paul Statham, Manlio Cinalli, Endre Sik, Bo Bengtsson, and Jon Rogstad.

iii The surveys were conducted in person in London, Oslo and Stockholm, and by phone in Geneva due to the high cost of face-to-face surveys in Switzerland. See Morales and Giugni (2011) for more details on the characteristics of the samples. In our samples, there are no relevant differences between the autochthonous population and the first generations of immigrants in terms of their age profile, but $2^{\text {nd }}$ generations and children of mixed marriages tend to be much younger — especially in Oslo and Stockholm, where more than 50 per cent are less than 36 years old. All groups are much more balanced in terms of gender, though first generations in London and second generations in Oslo are predominantly male — both at 61 per cent.

iv The more restrictive requirements in Geneva -8 years of residence - mean that 55 per cent of the migrant-background individuals interviewed in that city were not eligible to vote in local elections, as they reported in response to our questionannire; thus, they are excluded from our analyses. The equivalent figure was 11 per cent for Oslo, 8 per cent for London and 7 per cent for Stockholm, reflecting less demanding rules for eligibility. Hence, the immigrant-background electorate in Geneva 
is more 'selective' - at least in terms of length of residence — and less representative of the overall immigrant-background population in that city than the respective electorates in the other cities studied. ${ }^{v}$ The exact wording of the questions was: 'Sometimes people don't vote because they cannot or because they don't want to. Did you vote in the last [name of host country parliament] elections, or was there anything that made you unable or unwilling to vote? (INT: If respondent answers no, ask if he/she was eligible to vote or not.) And did you vote in the last local elections? (INT: If respondent answers no, ask if he/she was eligible to vote or not.)'

${ }^{\text {vi }}$ Of course, the fact that we focus on the citizen/foreign distinction does not mean that the national origin of the immigrant groups is irrelevant. However, our analyses (not shown) indicate that these gaps hold for most migrant groups studied across cities.

vii We run four separate logistic regression models, one per city, with the same control variables: citizenship of the country of residence, age (also in quadratic form), gender, educational level, employment status, whether in a relationship (married or with partner) or not, spouse/partner is autochthonous, more than half of respondent's life spent in the host country, and fluent in country/city language. The model also included a dummy for the children of mixed couples, but given the lack of precision in the estimations due to sample sizes, we have left this group out of the graph. The probabilities in Figure 1 have been calculated for a hypothetical 40 years-old male respondent who is employed, with an educational level equal to the mean educational level in his city of residence, living with a non-autochthonous partner, who has lived in the country for more than half of his life and is fluent in the country/city language.

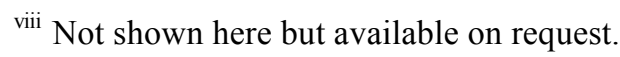

ix The non-fluent eligible respondents are 13 per cent in Geneva, 12 in Oslo, 9 in London and 7 in Stockholm.

\section{References}

Berry, J. W., Phinney, J. S., Sam, D. L., et al. (eds.) (2006) Immigrant Youth in Cultural Transition. Acculturation, Identity, and Adaptation across National Contexts, Mahwah, NJ: Lawrence Erlbaum Associates Inc. Publishers. 
Bird, K., Tiberj, V., Saalfeld, T., et al. (2011) 'Voter turnout among immigrants and visible minorities in comparative perspective', in K. Bird, T. Saalfeld and A. M. Wüst (eds.) The Political Representation of Immigrants and Minorities: Voters, Parties and Parliaments in Liberal Democracies, London: Routledge, pp. 25-65.

Bloemraad, I. (2006) Becoming a Citizen. Incorporating immigrants and refugees in the United States and Canada, Los Angeles: University of California Press.

Bousetta, H. (2000) Immigration, post-immigration politics and the political mobilisation of ethnic minorities. A comparative case-study of Moroccans in four European cities, Brussels: IPSoM.

Cinalli, M. and Giugni, M. G. (2011) 'Institutional opportunities, discursive opportunities and the political participation of migrants in European cities', in L. Morales and M.G. Giugni (eds.) Social Capital, Political Participation and Migration in Europe. Making Multicultural Democracy Work?, Basingstoke: Palgrave, pp. 43-62.

Garbaye, R. (2002) 'Ethnic minority participation in British and French cities: a historical-institutionalist perspective', International Journal of Urban and Regional Research, 26(3): 555-570.

Giugni, M. G. and Passy, F. (2004) 'Migrant Mobilization between Political Institutions and Citizenship Regimes: A Comparison of France and Switzerland', Swiss Political Science Review, 43(1): 51-82.

González-Ferrer, A. (2011) 'The Electoral Participation of Naturalized Immigrants in Ten European Cities', in L. Morales and M.G. Giugni (eds.) Social Capital, Political Participation and Migration in Europe. Making Multicultural Democracy Work?, Basingstoke: Palgrave, pp. 63-86. 
Howard, M. M. (2009) The politics of citizenship in Europe, New York: Cambridge University Press.

Huddleston, T., Niessen, J., Chaoimh, E. N., et al. (2011) Migrant Integration Policy Index III, Brussels: British Council and Migration Policy Group.

Ireland, P. (2000) 'Reaping what they Sow: Institutions and Immigrant Political Participation in Western Europe', in R. Koopmans and P. Statham (eds.) Challenging Immigration and Ethnic Relations Politics. Comparative European Perspectives, Oxford: Oxford University Press, pp. 233-282.

Jones-Correa, M. (1998) Between two nations. The political predicament of Latinos in New York City, Ithaca: Cornell University Press.

Koopmans, R. and Statham, P. (2000) 'Migration and Ethnic Relations as a Field of Political Contention: An Opportunity Structure Approach', in R. Koopmans and P. Statham (eds.) Challenging Immigration and Ethnic Relations Politics, Oxford: Oxford University Press, pp. 13-56.

Koopmans, R., Statham, P., Giugni, M. G., et al. (2005) Contested Citizenship. Immigration and Cultural Diversity in Europe, Minneapolis: University of Minnesota Press.

Morales, L. and Giugni, M. G. (eds.) (2011) Social Capital, Political Participation and Migration in Europe. Making Multicultural Democracy Work?, Basingstoke: Palgrave.

Niessen, J., Huddleston, T. and Citron, L. (2007) Migrant Integration Policy Index, Brussels: British Council and Migration Policy Group.

Bios: 
Bios:

Amparo González-Ferrer is Research Fellow at the Center for Humanities \& Social Sciences (CCHS) of the Spanish Research Council (CSIC). Her research interests lie in the areas of social demography, international migration and integration policies. She is currently engaged in two major projects on the dynamics of migration between Africa and Europe, and on the life-course perspectives of descendants of immigrants in Southern Europe.

Laura Morales is Reader in Politics in the Department of Politics and International Relations of University of Leicester. Her interests lie, especially, in the areas of political behaviour, political parties, the politics of immigration, and comparative politics. She is currently engaged in several projects on the politics of immigration, and on civic and political participation in established democracies. 